\title{
Kansalliskirjaston sanomalehtiaineistot: käyttäjät ja tutkijat kesällä 2018
}

\author{
Tuula Pääkkönen \\ Kansalliskirjasto \\ tuula.paakkonen@helsinki.fi \\ https://orcid.org/0000-0003-3958-9732 \\ Kimmo Kettunen \\ Kansalliskirjasto \\ kimmo.kettunen@helsinki.fi \\ https://orcid.org/0000-0003-2747-1382
}

Kansalliskirjaston digitoitujen aineistojen verkkopalvelussa Digi.kansalliskirjasto.fi järjestettiin käyttäjäkysely kesäkuun 2018 puolivälistä eteenpäin. Kysely oli avoinna aluksi kesäkuun loppuun, mutta jätettiin auki vielä heinäkuuksi lisävastaajien saamiseksi. Vastaajia saatiin lopulta 140. Kyselyn tavoitteena oli toimia perustason arviona, josta saadaan lähtötietoja palvelun käyttäjistä, käytetyistä aineistoista ja toiminnoista. Tämän perusteella voimme jatkossa arvioida ovatko palveluun tehdyt muutokset vaikuttaneet palvelun käyttöön. Yhtenä osana yritimme myös selvittää tutkimuskäytön luonnetta ja osuutta palvelun kokonaiskäytöstä. Joitakin vastauksia saatetaan myös hyödyntää aineistojen avaamisen jatkoneuvotteluissa tekijänoikeusjärjestöjen kanssa.

Luokittelimme sivuston yleisen käyttötarkoituksen taulukossa 1 näkyviin luokkiin: tieteellinen tutkimus, korkeakouluopinnot, sukututkimus, tutkimus yksityisiin tarpeisiin, tutkimus oman organisaation/yrityksen tarpeisiin, peruskouluopinnot, selailu ja muu. Tähän monivalintakysymykseen tuli yllättävän erilaisia yhdistelmiä - sukututkimus oli käytön kärjessä, mutta sen yhteydessä oli myös tutkimuskäyttöä.

Artikkeli on lisensoitu Creative Commons Nimeä-EiKaupallinen-JaaSamoin 4.o Kansainvälinen -lisenssillä

Pysyvä osoite: https://doi.org/10.23978/inf.76067 


\begin{tabular}{lrrr}
\hline Käyttötarkoitus & Vastauksia (N) & Vastauksia (\%) & \% tapauksista \\
\hline Tieteellinen tutkimus & 26 & $11,3 \%$ & $18,6 \%$ \\
Korkeakouluopinnot & 13 & $5,7 \%$ & $9,3 \%$ \\
Sukututkimus & 83 & $36,1 \%$ & $59,3 \%$ \\
Tutkimus yksityisiin tarpeisiin & 40 & $17,4 \%$ & $28,6 \%$ \\
Tutkimus oman organisaation / yrityksen tarpeisiin & 18 & $7,8 \%$ & $12,9 \%$ \\
Peruskouluopinnot & 1 & $0,4 \%$ & $0,7 \%$ \\
Selailu & 39 & $17,0 \%$ & $27,9 \%$ \\
Muu & 10 & $4,3 \%$ & $7,1 \%$ \\
\hline Yhteensä & 230 & $100,0 \%$ & $164,3 \%$
\end{tabular}

Taulukko 1: Sivuston käyttötarkoitus

\begin{tabular}{lrr}
\hline Tieteenala & Lkm & $\mathrm{N} \%$ \\
\hline 113 Tietojenkäsittely ja informaatiotieteet & 84 & $60,0 \%$ \\
1181 Ekologia, evoluutiobiologia & 3 & $2,1 \%$ \\
212 Rakennus- ja yhdyskuntatekniikka & 2 & $1,4 \%$ \\
214 Kone- ja valmistustekniikka & 1 & $0,7 \%$ \\
3112 Neurotieteet & 1 & $0,7 \%$ \\
316 Hoitotiede & 1 & $0,7 \%$ \\
415 Muut maataloustieteet & 1 & $0,7 \%$ \\
513 Oikeustiede & 1 & $0,7 \%$ \\
5141 Sosiologia & 1 & $0,7 \%$ \\
516 Kasvatustieteet & 1 & $0,7 \%$ \\
519 Yhteiskuntamaantiede, talousmaantiede & 2 & $1,4 \%$ \\
520 Muut yhteiskuntatieteet & 1 & $0,7 \%$ \\
6121 Kielitieteet & 2 & $1,4 \%$ \\
6122 Kirjallisuuden tutkimus & 2 & $1,4 \%$ \\
6131 Teatteri, tanssi, musiikki, muut esittävät taiteet & 1 & $0,7 \%$ \\
6132 Kuvataide ja muotoilu & 1 & $0,7 \%$ \\
614 Teologia & 2 & $1,4 \%$ \\
615 Historia ja arkeologia & 1 & $0,7 \%$ \\
616 Muut humanistiset tieteet & 31 & $22,1 \%$ \\
\hline Yhteensä & 1 & $0,7 \%$ \\
\hline
\end{tabular}

Taulukko 2: Minkä tieteenalan tutkimusta teet? Käytön tieteenalakohtainen jakauma.

Kysymys käytön tieteenalasta tuli valittavaksi, jos aiemmasta kysymyksestä oli valinnut jonkin tutkimuksellisen käyttötarkoituksen. Kyselyn tieteenalat perustuvat Opetus- ja kulttuuriministeriön määritelmiin (Suomen Akatemia, 2016). Palvelun tieteenalakohtainen käyttö on esitetty taulukossa 2. Tieteenalan kysymys aktivoitui vastaajille, jos he olivat valinneet käyttötarkoitukseensa tutkimuksen, ja näin 84 henkilöä 140:stä päätyi tähän vastaamaan.

Historia ja arkeologia olivat selkeä kärkivalinta viidenneksellä vastaajista ja lopuissa vastauksissa näkyi tieteenalavalinnassa ns. "pitkä häntä”: 18 eri valintaa, joissa kaikissa oli 1-3 valintaa. Kokonaisuudessaan tutkimuskäytön 


\begin{tabular}{lrrr}
\hline Käytetty toiminto & Vastauksia (N) & Vastauksia (\%) & $\%$ tapauksista \\
\hline Vapaatekstihaku & 124 & $32,7 \%$ & $90,5 \%$ \\
Haun rajaus & 80 & $21,1 \%$ & $58,4 \%$ \\
Lehdet eli lehtinimekkeet (listaus & 73 & $19,3 \%$ & $53,3 \%$ \\
kaikista lehdistä) & & & \\
$\begin{array}{l}\text { Päivän sanomalehdet sata vuotta sitten } \\
\text { Leiketoiminnot (uuden luonti, }\end{array}$ & 18 & $4,7 \%$ & $13,1 \%$ \\
leikkeiden haku) & 24 & $6,3 \%$ & $17,5 \%$ \\
Sivupalkista avautuva lähdeviittauksen & & & $5,8 \%$ \\
tekeminen ("-työkalu) & & $2,1 \%$ & $19,7 \%$ \\
Niteen PDF:n lataus & 27 & $7,1 \%$ & $2,9 \%$ \\
Sosiaalisen median työkalut (leikkeiden & 4 & $1,1 \%$ & \\
jakaminen, kommentointi Facebook- tai & & & $2,9 \%$ \\
Twitter-palveluun) & & $1,1 \%$ & \\
$\begin{array}{l}\text { Aineistopakettien lataus } \\
\text { (digi.kansalliskirjasto.fi/opendata }\end{array}$ & 4 & & $2,9 \%$ \\
-sivulta) & & $1,1 \%$ & $5,8 \%$ \\
Useimmin kysytyt kysymykset & 4 & $2,1 \%$ & $1,5 \%$ \\
Haun ohje (oranssi ?-merkki & & & $2,2 \%$ \\
hakusivulla) & & $0,5 \%$ & $276,6 \%$ \\
Etusivun sivumäärätilastot & & $0,8 \%$ & \\
Leikkeiden kommentointi & 2 & $100,0 \%$ & \\
\hline Yhteensä & 3 & &
\end{tabular}

Taulukko 3: Käyttäjien toiminnot sivustolla

päätyi valitsemaan 84 eli $60 \%$ vastaajista. Palvelun erilainen tutkimuskäyttö jatkuu siis kesälläkin, vaikka ehkä sukututkimuksen tai muun selailun lomassa.

Palvelun aineistotyypeistä käytettiin eniten sanomalehtiä: $90 \%$ vastaajista valitsi ne. Aikakauslehdet olivat toisena, 55\%, ja pienpainatteet kolmantena, $28 \%$. Tämäkin kysymys oli monivalinta, joten jos oli käytetty yhtä aineistolajia, se oli vetänyt myös muun aineiston pariin.

\section{Toimintoja kaikille}

Kyselyssä selvitettiin myös käyttäjien sivuilla käyttämiä toimintoja. Vastaukset on esitetty taulukossa 3 .

Vapaatekstihaku oli käytössä lähes kaikilla (90,5\%), mutta pudotus siitä esimerkiksi haun tarkempaan rajaukseen oli yllättävän suuri: 58\% käytti apuna muita rajauksia, vaikka ne voisivat parantaa hakujen osuvuutta. Yllätyimme Lehdet-toiminnon suuresta suosiosta, mutta se on ehkä vain luonnollista, koska lehtien näkyvyys palvelun sivuilla on niin keskeinen. Lehden niteen lataaminen PDF:nä oli myös melko suosittua ja leikekäyttö tuntuu kasvavan: leikkeiden teko oli noussut viidenneksi suosituimmaksi toiminnoista. Tämä on näkynyt hyvin palveluun kertyneiden leikkeiden määrässä. 
Aineiston löytyvyyttä Digistä pidettiin hyvänä. Vastaajista $53 \%$ oli väitteen kanssa osin samaa mieltä, täysin samaa mieltä oli $27 \%$. Alle on listattu muutamia kommentteja, jotka eri arvosanat saivat (arvosanat asteikolla 1-5).

\begin{tabular}{cl}
\hline Arvosana & Kommentti \\
\hline 5 & Käyttö on helppoa. Haut toimivat. \\
5 & Det är enkelt, lätt och snabbt! \\
4 & Oikean hakusanan keksiminen joskus hankalaa \\
4 & tekoälyn terästämää fraktuuratekstin tunnistusta odotellessa \\
2 & Haen henkilöiden ja paikkojen nimillä. Usein haku ei löydä nimiä \\
2 & hain henkilöä x. koivu, vastauksena paljon koivuhalkoja \\
2 & tabletilla ongelmia hauissa \\
\hline
\end{tabular}

Pohdimme Kansalliskirjastossa usein hakulomakkeen hakuvaihtoehtoja ja siksi kysyimme käyttäjiltä myös hakuvaihtoehdoista. Käyttäjistä $42 \%$ oli osin samaa mieltä väitteen "hakuvaihtoehdot riittävät" kanssa ja 32\% oli täysin samaa mieltä väitteen kanssa. Joitakin tähän liittyviä kommentteja on lueteltu alla.

\begin{tabular}{cl}
\hline Arvosana & Kommentti \\
\hline 5 & Vaihtoehtoja tarpeeksi \\
5 & ristiinhakukin on mahdollista. \\
4 & Pitäisi olla mahdollisuus rajata pois tietyt asiat vastauksista \\
4 & Ns. Läheisyyshaku ei aina toimi halutusti. \\
2 & Ehkä sellainen "pois nämä vaihtoehdot" olisi hyvä. \\
& tulokset pitäisi näyttää koko lehden osalta ei vain 1 sivun \\
2 & voisi olla myös täsmähaku lainausmerkkien sisällä \\
\hline
\end{tabular}

Kysymys "Mitä etsit tänään” oli myös kiinnostava ja vahvisti aiempia vastauksia. 63 henkilöä oli kuvaillut päivän hakujaan, ja Kuva 1. esittää pääryhmät, joita vastauksista oli löydettävissä. Suku oli suurin yksittäinen teema, ja se sisälsi esimerkiksi sukulaisten nimien etsinnän ja kuolin- ja vihki-ilmoituksien etsinnän. Luokka Yleinen, johon sisältyy tutustuminen palveluun ja yleinen selailu ilman erityistä hakutarkoitusta, oli toiseksi suurin. Vastausten suuri määrä voi selittyä henkilöillä jotka olivat tulleet palveluun ensimmäistä kertaa tai vain vastaamaan kyselyyn. Historia-kategoriaan vastauksista luokiteltiin ne jotka etsivät tiettyä nimekettä tai lehtiä sadan vuoden takaa.

Kyselyn vapaiden vastausten osa oli kiinnostava. Suurimmat toiveet liittyivät joko tiettyjen aineistojen digitoimiseen tai tekijänoikeudellisiin kysymyksiin. Moni käyttäjä ei ymmärtänyt, miksi 1930-40-luvun lehtiä tai jopa sitä tuoreempia lehtiä ei voisi laittaa kaikille käyttöön. Lisäksi alettiin jo harmitella sitä, että jääkö vuosien 1918-1929 lehtien avaaminen vain vuoden pituiseksi - tälle toivottiin jatkoa. 


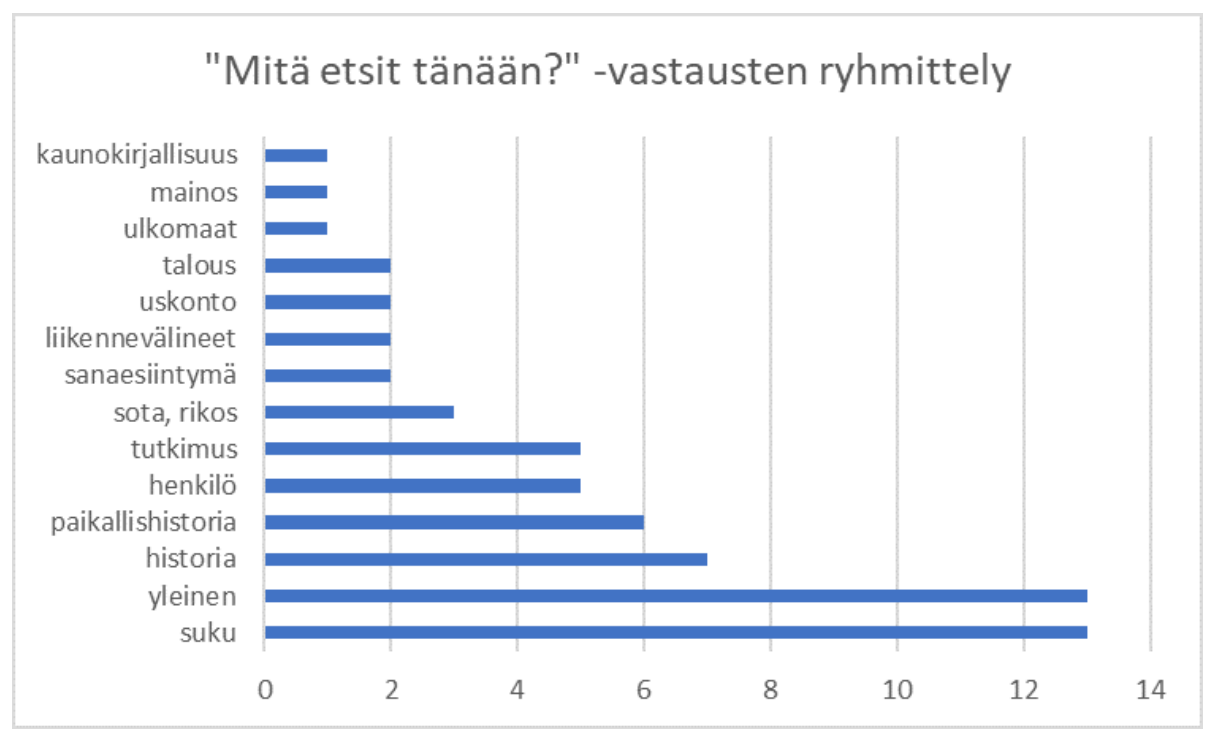

Kuva 1: Mitä etsit tänään -vastaukset

\section{Yhteenveto}

Olemme esitelleet Kansalliskirjaston digitoitujen aineistojen verkkopalvelun kesän 2018 käyttäjätutkimuksen tuloksia. Tulokset kertovat, että aineistoa käyttävät selvästi eniten sukututkijat, mikä on ollut aiempienkin käyttäjäselvitysten tulos (Hölttä, 2016; Matres, 2016). Varsinaisista tieteellisen tutkimuksen tekijöistä suurin joukko muodostuu historian ja arkeologian tutkijoista, ja luokituksen ja aineistojen luonteen vuoksi voisi olettaa, että käyttäjät ovat nimenomaan historioitsijoita, eivät arkeologeja. Palvelun ominaisuuksista käytetään eniten tekstihakua sekä haun rajausta. Myös lehtien listauksen selausta käytetään melko paljon. 80 prosenttia vastaajista piti aineistojen löytyvyyttä kohtuullisen hyvänä.

\section{Kirjallisuutta}

Hölttä, T. (2016). Digitoitujen kulttuuriperintöaineistojen tutkimuskäyttö ja tutkijat (Pro gradu -tutkielma). Tampereen yliopisto, Tampere. http://urn.fi/URN:NBN: fi:uta- 201603171337

Matres, I. (2016). Digital historical materials for academics, educators, hobbyists, creatives and browsers: the visitors evaluate digi.kansalliskirjasto.fi. Informaatiotutkimus, 35(3), 48-49. https://journal.fi/inf/article/view/59436

Suomen Akatemia. (2016). Tieteen tila 2016. http://www.aka.fi/fi/tiedepoliittinentoiminta/tieteen-tila/ajankohtaista/tieteen-tila-2016 